\title{
Assessing the impact of road transport infrastructure investment on economic development in South Africa
}

\begin{tabular}{|c|c|}
\hline \multicolumn{2}{|c|}{$\begin{array}{l}\text { Authors: } \\
\text { Anathi Hlotywa } \\
\text { Emeka A. Ndaguba }^{2}\end{array}$} \\
\hline \multicolumn{2}{|c|}{$\begin{array}{l}\text { Affiliations: } \\
{ }^{1} \text { Department of Economics, } \\
\text { University of Fort Hare, } \\
\text { South Africa }\end{array}$} \\
\hline \multicolumn{2}{|c|}{$\begin{array}{l}{ }^{2} \text { Institute of Development } \\
\text { Assistant Management, } \\
\text { University of Fort Hare, } \\
\text { South Africa }\end{array}$} \\
\hline \multicolumn{2}{|c|}{$\begin{array}{l}\text { Corresponding author: } \\
\text { Emeka Ndaguba, } \\
\text { endaguba@ufh.ac.za }\end{array}$} \\
\hline \multicolumn{2}{|c|}{$\begin{array}{l}\text { Dates: } \\
\text { Received: } 14 \text { June } 2017 \\
\text { Accepted: } 10 \text { July } 2017 \\
\text { Published: } 20 \text { Sept. } 2017\end{array}$} \\
\hline \multicolumn{2}{|c|}{$\begin{array}{l}\text { How to cite this article: } \\
\text { Hlotywa, A. \& Ndaguba, E.A., } \\
2017, \text { 'Assessing the impact } \\
\text { of road transport } \\
\text { infrastructure investment on } \\
\text { economic development in } \\
\text { South Africa', Journal of } \\
\text { Transport and Supply Chain } \\
\text { Management } 11(0), \text { a324. } \\
\text { https://doi.org/10.4102/ } \\
\text { jtscm.v11io.324 }\end{array}$} \\
\hline \multicolumn{2}{|c|}{$\begin{array}{l}\text { Copyright: } \\
\text { ○ 2017. The Authors } \\
\text { Licensee: AOSIS. This } \\
\text { is licensed under the } \\
\text { Creative Commons } \\
\text { Attribution License. }\end{array}$} \\
\hline \multicolumn{2}{|l|}{ Read online: } \\
\hline 回輨: & $\begin{array}{l}\text { Scan this QR } \\
\text { code with your } \\
\text { smart phone or } \\
\text { mobile device } \\
\text { to read online. }\end{array}$ \\
\hline
\end{tabular}

Background: There has been considerable decline in the investment on road transport infrastructure in recent times, as a result of the dwindling economic investment owing to lowering gross domestic product (GDP) since 2009.

Objective: The objective of this study was to examine the relationship between road transport investment (ROTI) and economic development (ED) in South Africa. This article adopts the Harrod-Domar (HD) model of economic growth and development theory, endogenous growth theory and Solow-Swan neoclassical growth model.

Method: Data were derived from the South African Reserve Bank, Quantec database and Statistics South Africa (StatsSA) between 1990 and 2014. It used time series, econometric models cointegration and vector error correction model (VECM) to analyse.

Result: The results of the estimation demonstrate that the explanatory variables account for approximately $86.7 \%$ variation in ED in South Africa. Therefore, there exists a positive relationship between ROTI and ED.

Conclusion: This study established a long-run relationship between phenomena and demonstrates the role of road transport investment on economic development in South Africa.

\section{Introduction}

The availability of road transport infrastructure investment (ROTI) in a country is of paramount importance, given that it enhances the economic chains and accelerates growth and development in the country. Various studies (Aschauer 1989; Fedderke \& Garlick 2008; Kayode, Babatunde \& Abiodun 2013; Pradhan 2010) have suggested that adequate road infrastructure investment boosts economic activities that tend to improve the living standard of the people, accelerate economic development (ED) and improve well-being, thereby enhancing the economics derived from the prudent allocation of resources within the geographical enclave. Environmental scientists, sustainability specialists, those knowledgeable in diversifying production and economies, poverty eradication practitioners and traders all attest to the efficacy of ardent transport infrastructure investment in improved standard of living and the minimum conditions for growth and development. Accordingly, Pradhan (2010) argues that having good ROTI in developing societies enhances people's standards of living, resulting in its ability to create jobs, increase economic activities and entrepreneurial activities as well as opportunities for the teeming youth population in the country.

It is imperative, therefore, to note that road transport infrastructural investment directly impacts $\mathrm{ED}$, creates jobs and improves well-being of the people within the geographical enclave. It serves as input in the production process of various goods and services leading to better quality of life, reduced cost production and a greater value for money, while providing opportunities for its teeming populace. Directly or indirectly, ROTI raises productivity of workers, reduces cost of transportation, reduces turnover time and provides safety within a country. All these antecedents paved the way for investment of all sorts on the one hand, and positive external total output that exceeds the private returns. Considering South Africa's curve in road transport infrastructural development since the dawn of democracy, one is tempted to note with caution that South Africa has one of the very best well-developed infrastructure investments, such as roads, among others, like health and educational facilities in the rural world in general and sub-Saharan Africa in particular. Yet, a bulk of infrastructure like roads, railways and ports require sizable investment on both maintenance and upgrade. This study is an attempt to establish the relationship between 
ROTI and ED in South Africa that is relatively not well exploited. A descriptive method based on empirical data and literature is pursued.

\section{Theoretical base}

There are a number of theories to explain the linkage between ED and road transport infrastructural investment. ED theories are treated in this case as an extension of conventional economic growth theory and therefore development was merely equated to growth. Hence, gross domestic product (GDP) was a proxy for overall ED. ED, in this sense, includes national production, social equity aspect such as elimination of poverty, inequality and unemployment (Hall 1983).

\section{Economic growth and development theory}

Domar (1946) and Harrod (1948) were among the foremost scholars to use Keynesian model to analyse ED in a closed economic framework. The Harrod-Domar model is based on three assumptions. Firstly, the economy generates savings (S) at a constant proportion (s) of national income (Y):

$\mathrm{S}=\mathrm{sY}$

[Eqn 1]

Where $s$ is the marginal and average saving ratio.

Secondly, the economy is in equilibrium, that is, planned investments equal planned savings:

$$
\mathrm{I}=\mathrm{S}
$$

Thirdly, investment is determined by the expected increase in national income $(\Delta \mathrm{Y})$ and a fixed technical coefficient known as incremental capital output ratio (ICOR):

$\mathrm{I}=\mathrm{v} \Delta \mathrm{Y}$

By definition, ED $(\mathrm{g})$ is the change in income per unit of income:

$\mathrm{g}=\Delta \mathrm{Y} / \mathrm{Y}$

[Eqn 4]

Substitution of the relationship in equation gives an alternative definition of growth as follows:

$\mathrm{g}=\mathrm{s} / \mathrm{v}$

[Eqn 5]

\section{Solow-Swan model (neoclassical growth model)}

This model was developed by Solow and Swan in 1956. They related the assumptions of the fixed ICOR and the labour usage in the Harrod-Domar (HD) model. Solow $(1956,1957)$ and Swan (1956) argued that technological progress enhances more input combinations that increase efficiency, leading to a higher level of economic growth and development. In this sense, the advancement of technology in ROTI will lead to higher economic gain for South Africa. More importantly, Arrow (1962) and Sheshinski (1967) advanced the model by observing behaviour that explains such increase in productivity because of technological progress. But on contrary, it reduces wages and employment in the sector. In all, Solow-Swan model stresses the significance of technological advancement in transformation in the levels of ED in a country.

\section{Endogenous growth theory}

According to the endogenous growth theory, the long-run growth rate and development depends on the provision of infrastructure services particularly road (Barro \& Sala-iMartin 2004). In addition, the role of government is to regulate and in some cases solve market failures associated with the various types of investment. Hence, any investment is crucial to economic growth and development, but transport investment creates the highest number of opportunities and employment in a country, Furthermore, endogenous growth theory argues that the nature of improved technology accessed by investment drives growth, thus, infrastructure investment may generate long-run ED.

\section{Empirical literature review}

Sturm, Kuper and De Haan (1996) examined the impact of ROTI on ED in Netherlands from 1853 to 1913 (pre-war period) using the time series data. The Granger causality tests and vector auto regression (VAR) are employed as estimation techniques in order to test the long-run relationship between road transport infrastructure and ED. Empirical results revealed that there is a negative relationship between ROTI and ED in the Netherlands.

Aschauer (1989) investigated the role of ROTI on ED in the United States of America for the period of 1949-1985 using the time series data. The Johannsen was utilised as the estimation technique. The findings showed that road transport investment is an important element for ED in the United States. Hence, a positive relationship was established. There was a bi-causality relationship between road transport capital and ED.

Montolio and Solé-Ollé (2009a) analysed the impact of public ROTI on ED in Spain. The data covered the period from 1990 to 2009. The empirical model was developed from the endogenous growth framework in which transport investment entered into the production function as input. The VAR was used as the estimation technique, and the time series properties tests were conducted on variables. The findings showed that road transportation played a significant role in the determination of ED in Spain. Montolio and SoléOllé (2009b) study, therefore, argued that there existed a positive relationship between road transport investment and ED.

Looney (1997) investigated the role of ROTI on ED in Pakistan from 1973 to 1990 using the time series data. In his study, he incorporated other various types of infrastructure like energy and general on the Pakistan's private investment level. The VAR was employed as estimation technique in order 
to test the long-run relationship between road transport infrastructure and ED. Looney (1997) in Pakistan also affirmed that a positive relationship between ROTI and ED is inevitable.

Kayode et al. (2013) analysed the impact of public ROTI on ED using Nigeria as a case study. The data covered the period from 1977 to 2009 in time series form. The empirical model was developed from the endogenous growth framework in which transport investment entered into the production function as input. The ordinary least squares (OLS) was used as the estimation technique, and the time series properties tests was conducted on variables. The findings showed that road transportation played an insignificant role in the determination of ED in Nigeria. Therefore, there is a negative relationship between road transport investment and ED. An increase in public funding and complete overhauling of the road transportation system in Nigeria was suggested.

Ashipala and Haimbodi (2003) dealt with the relationship between public road infrastructure investment and ED in South Africa from 1990 to 2010 using the vector error correction model (VECM) as the estimation technique. The study found among other things that there is a positive relationship between public road infrastructure investments and ED in South Africa because as the economy grows, investment in public goods improves, which is consistent with the Keynesian theory and Wagner's law.

South Africa has a better ROTI as compared with other emerging countries in the South. The ROTI recovered rising from $2.76 \%$ of GDP in 2004, 2.90\% in 2005, 6.05\% in 2008 and $7.64 \%$ in 2009 (Fedderke \& Garlick 2008). The recovery was because of the government's infrastructure investment policy and the preparation of the 2010 FIFA World Cup. Since then, it has continued to dwindle. This is not squarely on the squabbles that surrounded the hosting of the World Cup or its completion. But to other competition economic forces as, inflation, purchasing power parity, downgrade, unemployment, and most severely the economic recession of 2007/08/09 and 2017 that still stifle the purse of the government.

Perkins, Fedderke and Luiz (2005) analysed long-term trends in the development of South Africa's economic infrastructure investment on long-term ED from 1992 to 2009. A database covering railways, roads, ports, air travel, phone lines and electricity was established. The Pesaran, Shin and Smith (PSS) F-tests were used to identify directions of association between economic infrastructure and ED. The empirical results revealed a positive relationship between economic infrastructure investment and ED in South Africa.

According to Fedderke and Bogeti (n.d.), the impact of road infrastructural investment on ED in South Africa over the period of 1970-2000 is enormous. They used the panel data analysis method and pooled mean group (PMG) estimator of Pesaran, Shin and Smith (2001) employing unrestricted error correction Autoregressive Distributed Lag (ARDL) model. The finding results revealed a positive relationship between infrastructure investments and ED in South Africa.

While for instance, Perkins et al. (2005) used PSS F-tests between 1992 and 2009 and Fedderke and Bogeti (n.d.) discussion of road transport and ED used panel data analysis method and PMG estimator and the ARDL model between 1970 and 2000. This study uses VECM AR Roots Johansen cointegration in establishing this relationship between 1990 and 2014.

Though, having a better ROTI is paramount. Because several empirical studies (Aschauer 1989; Fedderke \& Garlick 2008; Kayode et al. 2013; Pradhan 2010) have argued that, such an investment enhances ED. Recent activities, especially corruption, are one of the most perilous circumstances that threaten ROTIs in the country. Most of the road construction contracts in the country have become a source of political settlement than an investment. A typical example is the Alice-King William Town road which was poorly constructed between January 2016 and July 2016 and later re-awarded to a competent contractor. Also, most road rehabilitation or maintenance is given to stalwart of a party. The intersection of politics in development is rather causing a negative decline in road transport investment than otherwise. Considering the notion that there are several competing economic factors as (youth) unemployment, increasing poverty rate, and widening inequality gap, the country is beginning to focus on other competing national agenda at the expense of ROTI. Another problem is that because the HD model argues that 'investment is determined by the expected increase in national income', then with a dwindling national income, the opportunities that should have boost economic activities that lead to economic growth or development are also threatened. More so, the fact that ROTI is capital intensive makes the matter worse off for the industry. Therefore, the ROTI is at a risk in the country.

\section{Research methodology}

All research known to mankind are based on some underlying philosophical assumptions on what constitutes validity and reliability. The econometric models - cointegration and VECM is used to test the relationship between ROTI and ED in South Africa.

\section{Model specification}

In examining the relationship between ROTI and ED, the study employed econometric technique. According to the endogenous growth theory, the long-run ED depends on the provision of infrastructure services particularly road (Barro \& Sala-i-Martin 2004; Domar 1946; Harrod 1948).

Based on the theoretical considerations discussed, the model is specified as follows:

$E D=f(R O T I, G E N O T, E X C H, I)$

[Eqn 6] 
Where, ED represents economic development, ROTI is the road transport investment, GENOT is government expenditure on road transport, $\mathrm{EXCH}$ is the exchange rate and I represents income.

The empirical model used in the study is consistent with that of Perkin et al. (2005). It can be estimated as follows:

$$
\begin{gathered}
E D_{t}=\alpha_{t}+\beta_{1} \text { ROTI }_{t}+\beta_{2} \text { GENOT }_{t} \\
+\beta_{3} E X C H_{t}+\beta_{4} I_{t}+\mu_{t}
\end{gathered}
$$

\section{Cointegration test}

Cointegration is a statistical implication of the existence of a long-run relationship between the economic variables (Inder 1993). The main reason for the use of cointegration in the study is that it provides a formal background for testing and estimating short-run and long relationships among the economic variables. There are two alternative techniques for running cointegration tests: the Engle and Granger (1987) two-step tests and the maximum likelihood method developed by Johansen (1988). The Johansen technique is of particular interest for this study because less errors are involved in this approach as only one step is involved rather than the two steps required in the Engle-Granger technique. The Johansen cointegration test is considered a more powerful cointegration test, particularly when a multivariate model is used.

\section{Johansen cointegration test}

The Johansen cointegration test is robust to various departures from normality in that it allows any of the four variables in the model used as the dependent variable while maintaining the same cointegration results. The cointegration and causality tests were carried out only on the stationary variables, $\mathrm{I}(1)$ or $\mathrm{I}(0)$. In the Johansen technique for cointegration, we test for $r$ (the maximum number of cointegration relationships) which also includes testing procedures for linear restrictions on the cointegrating parameters, for any set of variables. In this technique, two statistics are used to identify the number of cointegrating vectors: the trace test statistic and the maximum-eigenvalue test statistic. The trace statistics evaluates the null hypothesis that there are at most $r$ cointegrating vectors, whereas the maximum-eigenvalue test evaluates the null hypothesis that there are exactly $r$ cointegrating vectors in $x_{t}$.

\section{Definition of variables and a prior expectations}

The endogenous growth theory argues that the provision of ROTI increases ED (Barro \& Sala-i-Martin 2004). Therefore, a positive relationship between ROTI and ED is expected. GENOT is the government expenditure on road transport, and a positive relationship between GENOT and ED is expected as the endogenous growth theory attest. Moreover, a positive relationship is expected between exchange rate $(\mathrm{EXCH})$ and $\mathrm{ED}$ as the theory asserts. I is income, the economic growth theory presumes that ED depends on per capita income implying that any increase in income will also result in a GDP which in turn influences ED. Therefore, a positive relationship is expected.

\section{Data sources}

The secondary data employed in the study are from 1990 to 2014 in quarterly time series. Data for the variables are obtained from the South African Reserve Bank, Statistics South Africa and Quantec database.

\section{General comment}

\section{Empirical analysis and interpretation of results}

\section{Stationarity analysis}

This study uses time series data in testing the stationarity properties. According to Brooks, stationary series can be defined as one with constant mean, constant variance and constant autocovariances for each lag (Brooks 2008:318). In empirical analysis, data are tested for stationarity in reaction to the problems that non-stationary time series data impose on the tested variables. The use of nonstationarity time series data leads to spurious regression where a relationship is found on unrelated time series. The informal ways of testing stationarity is the use of graphs. Formal tests such as the Augmented Dickey-Fuller (ADF) and the Phillips-Perron (PP) tests will test for stationarity in this study.

\section{Graphical analysis}

The informal tests were carried out through graphical inspections and the results are presented in Figure 1.

Figure 1 shows the plots of non-differenced logged values of all the variables under investigation. The results presented in Figure 1 suggests an upward trend for ED, ROTI, GENOT, EXCH and I tested variables and downward trend for ED, ROTI, GENOT, EXCH and I. The tested variables reveal evidence of non-stationary at levels as they all do not fluctuate around the mean. Additionally, it demonstrates that the variables exhibit a huge fluctuation of the variables around the mean. Considering that even after differencing, there are still variables with variances that are not steady, the study cannot conclude stationarity at this stage, and this requires the study to further carry out formal unit root test.

\section{Augmented Dickey-Fuller test}

In the ADF, the test adjusts the notion that error terms are independently and identically distributed. The ADF test is based on the hypothesis which states that:

- Hypothesis $0\left(H_{0}\right)$ : Non-stationary

- Hypothesis $1\left(H_{1}\right)$ : Stationary

The results of the ADF test consist of the $t$ statistic and the critical values of a zero coefficient. If the $t$ statistic is greater than the critical value, then the time series data are said to 

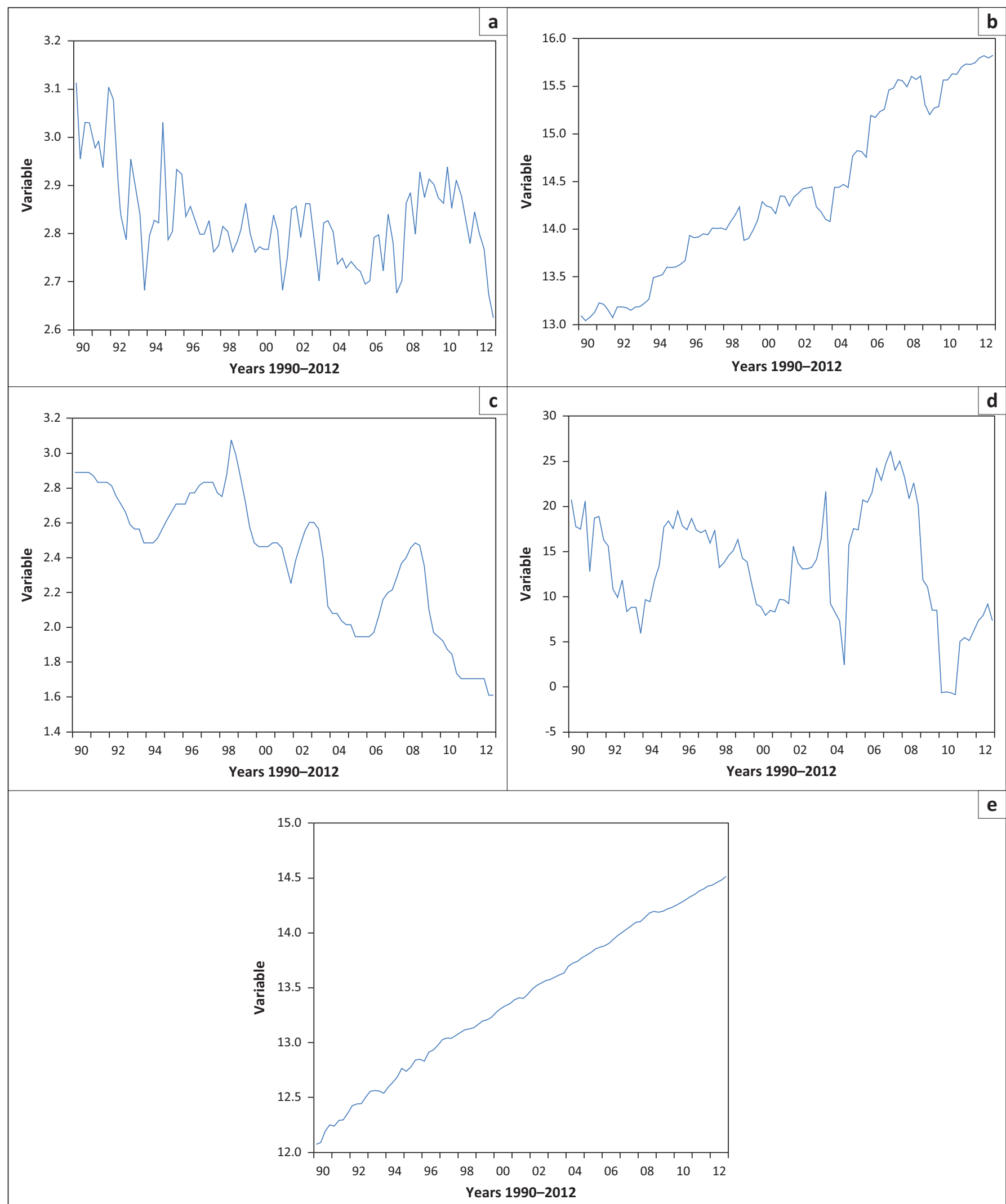

FIGURE 1: Stationarity graphs at levels. (a) Economic development, (b), road transport investment (c) government expenditure on road transport, (d) income and (e) exchange rate.

be non-stationary and unit root exists. In this case, the null hypothesis is not rejected. If the $t$ statistic is less than the critical values, time series data are stationary and unit root does not exist therefore the null hypothesis is rejected.

\section{Phillips-Perron test}

The PP tests are performed to complement the ADF test because the former test can properly distinguish between stationary and non-stationary time series with high degree of 
autocorrelation and presence of structural break. The $\mathrm{PP}$ test is a more comprehensive theory of unit root testing. The PP tests are analogous to ADF tests, but they incorporate an automatic correction to the Dickey Fuller (DF) procedure to allow for auto-correlated residuals and usually give the same conclusions as the ADF tests (Gujarati 2004).

\section{Stationarity result analysis}

Results from Tables 1 and 2 show that when the ADF and PP tests are implied, the ED is non-stationary on the level series of the data. However, on first difference using ADF, ED is stationary on intercept (10\% level of significance) and none (1\% level of significance). Using PP, the ED is stationary at intercept, trend and intercept and none (1\% level of significance).

ROTI is non-stationary at level series using ADF but becomes stationary when using PP at $1 \%$ level of significance on the level series. GENOT is non-stationary at both ADF and PP at level series. At first difference, using ADF, GENOT is stationary at none ( $10 \%$ level of significance) and stationary at $1 \%$ level of significance on intercept, trend and intercept and none when using the PP test. EXCH is stationary at first difference series at intercept (10\% level significance) and none (5\% level of significance) when using ADF. Income (I) is stationary at $1 \%$ level of significance when using PP at intercept, trend and intercept and none.

The results suggest that all variables examined are not stationary at levels, which therefore implies that they are integrated of I (1) as the critical values are less than computed values and this require further differencing.

Table 4 shows that the ADF and PP tests results of all variables under investigation are stationary in first difference. Having found that both methods suggest similar

TABLE 1: Unit root tests: Level series.

\begin{tabular}{|c|c|c|c|c|c|c|}
\hline \multirow[t]{2}{*}{ Variable } & \multicolumn{3}{|c|}{ Augmented Dickey-Fuller test } & \multicolumn{3}{|c|}{ Phillips-Perron test } \\
\hline & Constant & Constant and trend & None & Constant & Constant and trend & None \\
\hline ED & -1.634228 & -0.058578 & -1.144787 & -0.634228 & -0.058578 & -2.081128 \\
\hline ROTI & -0.385265 & -2.949198 & 2.529187 & 0.229008 & -2.926668 & 3.182100 \\
\hline GENOT & -1.398313 & -3.283108 & -1.321925 & -0.759928 & -2.308931 & -1.408210 \\
\hline $\mathrm{EXCH}$ & -1.950194 & -3.481184 & 11.39549 & -3.182252 & -3.362199 & 12.98635 \\
\hline 1 & 2.486681 & -0.358819 & -2.728705 & -8.218482 & -9.022105 & -2.275511 \\
\hline
\end{tabular}

ED, economic development; ROTI, road transport investment; GENOT, government expenditure on road transport; EXCH, exchange rate; I, income.

TABLE 2: Unit root tests: First difference series.

\begin{tabular}{|c|c|c|c|c|c|c|}
\hline \multirow[t]{2}{*}{ Variable } & \multicolumn{3}{|c|}{ Augmented Dickey-Fuller test } & \multicolumn{3}{|c|}{ Phillips-Perron test } \\
\hline & Constant & Constant and trend & None & Constant & Constant and trend & None \\
\hline ED & $-9.476293 * *$ & $-9.435986 *$ & $-9.520240 *$ & $-46.72715^{*}$ & $-47.07350 *$ & $-46.95288^{*}$ \\
\hline ROTI & $-8.942108 * *$ & $-8.887047^{*}$ & $-8.996896 *$ & $-47.41466 *$ & $-47.34633^{*}$ & $-47.76597 *$ \\
\hline GENOT & $-8.990376 * *$ & $-8.936771 *$ & $-9.043588 *$ & $-15.24158^{*}$ & $-15.01964 *$ & $-15.39976 *$ \\
\hline $\mathrm{EXCH}$ & $-9.060199 * *$ & $-8.995857^{*}$ & $-9.121416^{*}$ & $-37.17517 *$ & $-42.35735^{*}$ & $-35.10184 *$ \\
\hline 1 & $-10.90503 * *$ & $-10.84363 * *$ & $-10.96445 * *$ & $-38.23886 *$ & $-37.70277^{*}$ & $-37.835058^{*}$ \\
\hline
\end{tabular}

ED, economic development; ROTI, road transport investment; GENOT, government expenditure on road transport; EXCH, exchange rate; I, income.

$* *$, significance at $5 \%$; , significance at $10 \%$.

TABLE 3: Cointegrating relations.

\begin{tabular}{lccc}
\hline Hypothesised number of CE(s) & Trace statistic & $\mathbf{0 . 0 5}$ critical value & Maximum eigen statistics \\
\hline None* & 64.73021 & 47.85613 & $\mathbf{0 . 0 5}$ critical value \\
At most 1* & 25.59389 & 29.13632 & 27.58438 \\
At most 2 & 12.31189 & 15.49707 & 21.13162 \\
At most 3 & 2.64209 & 3.841466 & 9.669798 \\
\hline
\end{tabular}

Source: MacKinnon, J., Haug, A. \& Michelis, L., 1999, 'Numerical distribution functions of likelihood ratio tests for cointegration', Journal of Applied Econometrics 14(5), 563-577

$\mathrm{CE}$, competing endogenous.

Trace test indicates 1 cointegrating equations at the 0.05 level.

*, Denotes rejection of the hypothesis at the 0.05 level; MacKinnon, Haug and Michelis (1999) $p$-values.

TABLE 4: Vector error correction model results.

\begin{tabular}{lccc}
\hline Variable & Coefficient & Standard error & t Statistic \\
\hline C & -0.587486 & 5.086183 & 3.688633 \\
ROTI & 0.51927 & 0.221507 & 0.0004 \\
GENOTI & -0.010897 & 0.060236 & 0.0297 \\
EXCH & 0.509022 & 0.239206 & -0.182189 \\
I & 0.5925061 & 0.053237 & 2.477006 \\
$R^{2}$ & 0.866813 & - & -1.352108 \\
Adjusted $R^{2}$ & 0.801525 & - & - \\
\hline
\end{tabular}

ROTI, road transport investment; GENOTI, government expenditure on road transport; EXCH, exchange rate; I, income, $R^{2}$, explanatory variable; C, constant; ED, Dependant variable. 
results, the study can conclude that the series are all nonstationary at levels but stationary in first difference and all variables are integrated of $\mathrm{I}(0)$ and this allowed cointegration test to be carried out.

\section{Stationarity graphs after first differencing}

The variables were tested for the order of integration in first difference series and the results are presented in Figure 2.

\section{Lag length selection}

Brooks (2008) argues that there is a problem in determining the lag length when testing for stationarity. Choosing fewer lags will lead to the omission of relevant variable bias, whose consequences can be very serious. The coefficients can be consistently estimated by OLS, although their variances may be less efficient. The Akaike or Schwartz information criterion (SIC) can be used to choose the appropriate lag length. In this study, the lag length for each variable will be six based on the SIC.

\section{Cointegration test results}

Table 5 reports the trace and maximum eigen results whereas summary statistics of the original cointegration series are presented in Appendix 1. Cointegration results indicate that both the maximum eigen and trace statistics suggest the presence of one cointegrating equation among the four variables at $5 \%$ level in line with the Osterwald-Lenum critical values. The result of this test implies that there is a long-run equilibrium relationship between ED and road transport investment on the one hand, and the relationship between government expenditure, road transport, EXCH and income.

\section{Vector error correction model}

Because one cointegrating vector is found, estimation of VECM which adjusts to both short-run and long-run changes in variables and deviations from equilibrium follows:

$$
\begin{aligned}
\mathrm{ED}= & -0.587486+0.51927 \mathrm{ROTI}-0.010897 \text { GENOT } \\
& +0.509022 \mathrm{EXCH}+0.592506 \mathrm{I}+\mathrm{U}_{\mathrm{t}}
\end{aligned}
$$

The results of the estimation show that the explanatory variables account for approximately $86.7 \%$ variation in ED in South Africa. Therefore, there exists a positive relationship between ROTI and ED. Moreover, a positive relationship is expected between EXCH and ED as the theory asserts. I is income, the economic growth theory view on income provided that ED depends on income. It implies that an increase in income also increases ED. Therefore, a positive relationship is estimated. $R^{2}$ is also highly equal to $86 \%$ and this signifies that variation in the regression explains the variation on dependent variable to $86 \%$.

\section{Diagnostic tests results}

The VECM was subjected to rigorous diagnostic tests. Diagnostic checks are crucial in this analysis to establish if the assumptions which underlie the classical linear regression model is observed. The VECM was tested for AR Roots test and serial correlation and the results are indicated in Figure 3.

The AR Roots Graph reports the inverse roots of the characteristic AR polynomial. The estimated VECM is stable that is stationary if all roots have modulus less than one and lie inside the unit circle. In our case, as illustrated in Figure 3, all roots lie inside the unit circle which is an indication that our VECM is stable.

The residuals were also examined for the normality, autocorrelation and heteroscedasticity and the results are reported in Table 5.

Table 5 shows that the results do not suffer from autocorrelation, non-normality and heteroscedasticity. The results obtained from the analysis are therefore robust.

\section{Conclusion}

This article focused on interpreting the results of models estimated. This article began with analysing the time series properties of the data using three methods of testing for unit root. All three methods confirmed that the variables are integrated of order one, I(1). Having determined the order of integration of the variables, the lag length used in the estimation for the Johansen cointegration was determined empirically. This, therefore, implied that there is a long-term relationship between ED and its determinants. The VECM was also estimated to analyse both the long-run and the short-run interaction between the variables. The long-run equation showed that all the variables employed in the model are significant and carried the correct signs. The results also observed all the assumptions which underlie the classical linear regression model.

\section{Summary, findings, conclusion and limitations}

The strength of this article lies in reaffirming the established relationships of road transport infrastructural investment with ED. Taking into cognisance the significance and the challenges confronting road transport infrastructure investment in South Africa, this article argued that ROTI is pivotal to ED. Stretching from an introduction to empirical review, where other studies demonstrated similar tendencies around the world, in Africa and in South Africa as well, outlining the studies of Perkins, Fedderke and Luiz, and Fedderke and Bogeti conducted in South Africa, it stretches the discussion even further by providing an analysis between 1990 and 2014 using the VECM AR Roots Johansen cointegration in assessing the relationship.

Based on both theoretical and empirical literature, the study explains the impact of ROTI and ED. The model explains ED as a function of road transport investment, GENOT, EXCH and income. 

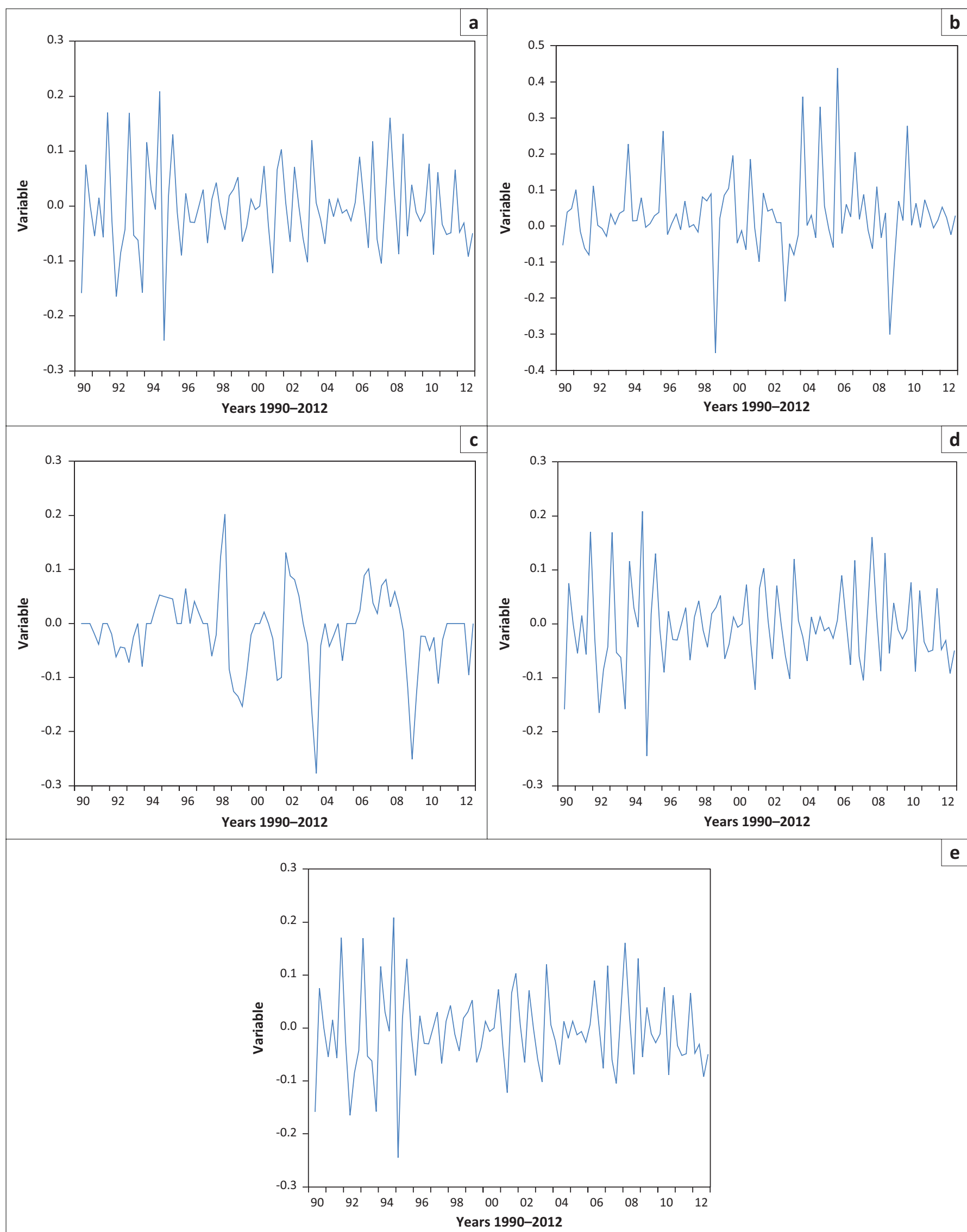

FIGURE 2: Differential series. (a) Economic development, (b), road transport investment (c) government expenditure on road transport, (d) exchange rate and (e) income. 
To empirically examine the run impact of ROTI on ED, the study employed Johansen's cointegration approach, and the VECM was employed as to capture both the short-run and long-run dynamics of the estimated model.

As it is common that macroeconomic time series are trended, in most cases the variables are nonstationary and using a non-stationary data may lead to invalid results and conclusion. For this reason, before conducting the cointegration test, the study first conducted the stationarity test for all variables under investigation using both the informal and formal tests. For the informal test, graphical inspections were used, while PP and ADF tests were applied in order to formally test for stationarity. Having found that the variables are stationary after first differencing and are integrated of the same order, the study further conducted a cointegration test to check if there exists a long-run relationship between the two variables.

The results revealed that there is cointegration among the variables under examination. With the first model, the trace statistics suggested three cointegrating vectors, whereas the maximum eigenvalue suggested two cointegrated vectors. With the latter, the trace statistics suggest two cointegrating vectors, whereas the maximum eigenvalue indicates that there is no cointegration. The presence of at least one cointegrating vector allowed for estimation of the VECM, which was followed by diagnostic checks through autocorrelation

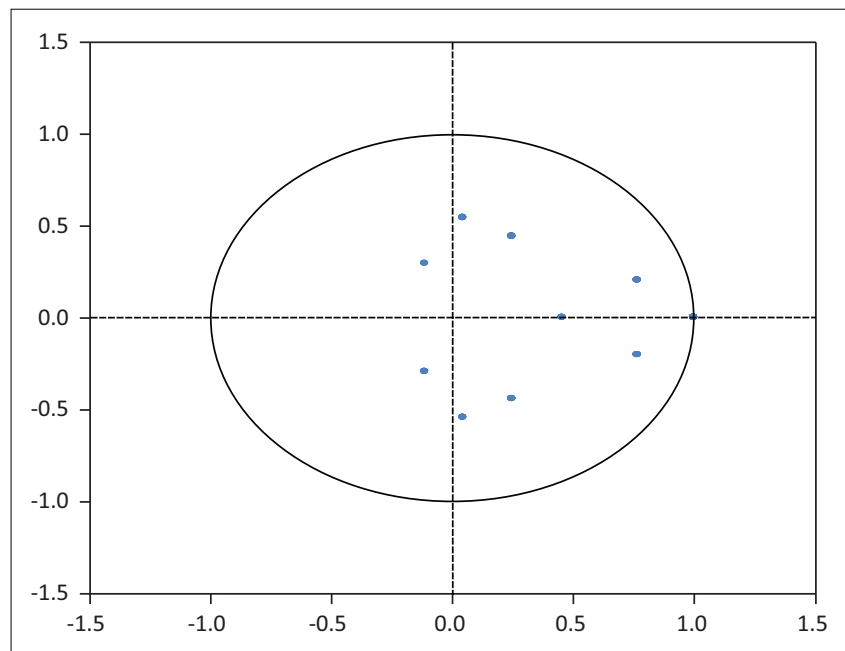

Source: Ncanywa, T. \& Makhenyane, L., 2016, 'Can Investment Activities in the Form of Capital Formation Influence Economic Growth in South Africa?', in M.P. Sebola \& J.P. Tsheola (eds.), SAAPAM Limpopo Chapter 5th Annual Conference Proceedings 2016, Mokopane, South Africa, October 26-28, 2016, p. 288

FIGURE 3: Inverse roots of AR characteristic polynomial.

TABLE 5: Other diagnostic tests.

\begin{tabular}{llccl}
\hline Test & \multicolumn{1}{c}{$\mathbf{H}_{0}$} & $\begin{array}{c}\text { Test } \\
\text { statistic }\end{array}$ & $p$ & Conclusion \\
\hline Jarque-Bera & $\begin{array}{l}\text { Residuals are normally } \\
\text { distributed. }\end{array}$ & 34.702 & 0.11 & $\begin{array}{l}\text { Errors are normally } \\
\text { distributed }\end{array}$ \\
$\begin{array}{l}\text { VEC residual } \\
\text { serial correlation } \\
\text { LM tests }\end{array}$ & $\begin{array}{l}\text { There is no serial } \\
\text { correlation in the } \\
\text { residuals. }\end{array}$ & 78.473 & 0.11 & $\begin{array}{l}\text { No second-order } \\
\text { autocorrelation }\end{array}$ \\
$\begin{array}{l}\text { VEC residual } \\
\text { heteroscedasticity } \\
\text { tests }\end{array}$ & $\begin{array}{l}\text { The residuals are } \\
\text { homoscedastic. }\end{array}$ & 86.082 & 0.35 & $\begin{array}{l}\text { No } \\
\text { heteroscedasticity }\end{array}$ \\
\hline VEC vector error correction: & & &
\end{tabular}

VEC, vector error correction; LM test, Lagrange multiplier test. (serial correlation), heteroscedasticity and normality of the residuals, the results from these tests are positive. These results are in accordance with most of the studies such as Peter et al. (2015) reviewed the literature in the sense that they confirm a long-run link between the two variables.

\section{Policy implications and recommendations}

In general, the results confirm the existence of a link between ROTI and ED in both models. Also, the nature of the relationship is in accordance with the a-priori expectations as presented in this article. It is interesting to find that the ROTI, as sophisticated as it is, contributes this more towards growth.

Given the results above, the study makes the following policy recommendations:

- The South African government should develop policies that encourage the incorporation of the ROTI into the economic system.

- Policy makers (Fiscal and Monetary) should embark on economic activities that enhance the link between ROTI and ED, such as, stimulating savings which in turn improves the level of investment. Considering that literature proves investment as the main channel through which ROTI contributes towards ED.

- Lastly, an environment that enables ROTI to directly impact ED should be created.

\section{Limitations of the study}

The use of data from mainly the South African Reserve Bank would limit the effect of the study to only the Reserved Bank analysis. Variables that were converted from annual to quarter might also result in the frequency disparities. This adjustment might have contributed to some of the challenges experienced in the study. Using the short vector error correction alone might portend another limitation on the contrary.

\section{Acknowledgements Competing interests}

The authors declare that they have no financial or personal relationships that may have inappropriately influenced them in writing this article.

\section{Authors' contributions}

A.H. was responsible for data generating and E.A.N. was responsible for synergy, correction and literature.

\section{References}

Arrow, K.J., 1962, 'The economic implications of learning by doing', Review of Economic Studies 29(3), 155-173. https://doi.org/10.2307/2295952

Aschauer, D., 1989, 'Is public expenditure productive?', Journal of Monetary Economics 23, 177-200. https://doi.org/10.1016/0304-3932(89)90047-0

Ashipala, J. \& Haimbodi, N., 2003, The impact of public investment on economic growth in Namibia, NEPRU Working Paper No. 88, viewed 09 November 2016, from www.unhabitat.org/pmss/getElectronicVersion 
Barro, R.J. \& Sala-i-Martin, X., 2004, One-sector models of endogenous growth Economic growth, 2nd edn., McGraw-Hill, New York, pp. 205-237. ISBN 0-262 02553-1

Brooks, C., 2008, Introductory econometrics for finance, Cambridge University Press, Business \& Economics, Cambridge.

Domar, E.D., 1946, 'Capital expansion, rate of growth and employment', Econometrica 14, 137-147. As reprinted in Domar (1957).

Engle, R.F. \& Granger, C.W., 1987, 'Co-integration and error correction: Representation, estimation, and testing', Econometrica 55(2), 251-276. https://doi org/10.2307/1913236

Fedderke, B. \& Garlick, S., 2008, Infrastructural investment in long-run economic growth Policy Paper Number 12 (May 26, 2008), University of Cape Town, Cape Town.

Fedderke, J. \& Bogeti, A., n.d., Infrastructure and growth in South Africa: Direct and indirect productivity impacts of 19 infrastructure measures, Working Paper Number 39, University of Cape Town, Cape Town.

Gujarati, D.N., 2004, Basic econometric, 4th edn., The McGraw-Hill Companies, New York.

Hall, T., 1983, 'A contribution to the theory of economic growth', Quarterly Journal of Economics 70(1), 65-94.

Harrod, R.F., 1948, Towards a dynamic economics: Some recent developments of economic theory and their application to policy, Macmillan, London.

Inder, B., 1993, 'Estimating long-run relationships in economics: A comparison of different approaches', Journal of Econometrics 57(1-3), 53-68.

Johansen, S., 1988, 'Statistical analysis of cointegration vectors', Journal of Economic Dynamics and Control 12(2-3), 231-254.

Kayode, O., Babatunde, O. \& Abiodun, F., 2013, 'An empirical analysis of transport infrastructure investment and economic growth in Nigeria', Social Science 2(6), 179-188. https://doi.org/10.11648/j.ss.20130206.12

Looney, R.E., 1997, 'Infrastructure and private investment in Pakistan', Journal of Asian Economics 23, 44-56.

MacKinnon, J., Haug, A. \& Michelis, L., 1999, 'Numerical distribution functions of likelihood ratio tests for cointegration', Journal of Applied Econometrics 14(5), 563-577.
Montolio, A. \& Soll-Olle, S., 2009a, 'Impact of public road transport infrastructure investment on economic development in Spain', International Journal of Economics 125, n.p.

Montolio, D. \& Solé-Ollé, A., 2009b, 'Road investment and regional productivity growth: the effects of vehicle intensity and congestion', Papers in Regional Science 88(1), 99-118. https://doi.org/10.1111/j.1435-5957.2008.00167.x

Ncanywa, T. \& Makhenyane, L., 2016, 'Can Investment Activities in the Form of Capital Formation Influence Economic Growth in South Africa?', in M.P. Sebola \& J.P. Tsheola (eds.), SAAPAM Limpopo Chapter 5th Annual Conference Proceedings 2016, Mokopane, South Africa, October 26-28, 2016, p. 288

Perkins, P., Fedderke, J.W. \& Luiz, J.M., 2005, 'An analysis of economic infrastructure investment in South Africa', South African Journal of Economics 73(2), 211-228. https://doi.org/10.1111/j.1813-6982.2005.00014.x

Pesaran, H.M., Shin, Y. \& Smith, R.J., 2001, 'Bounds testing approach to the analysis of long-run relationships', Journal of Applied Econometrics 16, 289-326.

Pradhan, R., 2010, 'Transport infrastructure, energy consumption and economic growth triangle in India: Cointegration and causality analysis', Journal of Sustainable Development 3(2), 167-173. https://doi.org/10.5539/jsd. v3n2p167

Sheshinski, E., 1967, 'Optimal accumulation with learning by doing', in K. Shell (ed.), Essays on the theory of optimal economic growth, pp. 31-52, Mass, MIT Press, Cambridge.

Solow, R.M., 1956, 'A contribution to the theory of economic growth', Quarterly Journal of Economics Oxford Journals 70(1), 65-94. JSTOR 1884513. https://doi. org $/ 10.2307 / 1884513$

Solow, R.M., 1957, 'Technical change and the aggregate production function', Review of Economics and Statistics. The MIT Press 39(3), 312-320. JSTOR 1926047 https://doi.org/10.2307/1926047

Sturm, J.-E., Kuper, G. \& De Haan, J., 1996, Modelling government investment and economic growth on a macro level: A review, p. 29, University of Groningen, Groningen, Netherlands.

Swan, T.W., 1956, 'Economic growth and capital accumulation', Economic Record.' Wiley 32(2), 334-361. https://doi.org/10.1111/j.1475-4932.1956. tb00434.x 


\section{Appendix 1}

TABLE 1-A1: Vector error correction estimates.

\begin{tabular}{|c|c|c|c|c|}
\hline Cointegrating Eq: & CointEq1 & & & \\
\hline \multicolumn{5}{|c|}{$\begin{array}{l}\text { Date: } 11 / 10 / 16 \\
\text { Time: } 16: 35 \\
\text { Sample (adjusted): } 199104 \text { 2010Q4 } \\
\text { Included observations: } 77 \text { after adjustments } \\
\text { Standard errors in ( ) \& t-statistics in [ ] } \\
\end{array}$} \\
\hline $\mathrm{ED}(-1)$ & 1.000000 & & & \\
\hline \multirow[t]{2}{*}{ ROTI(-1) } & 0.519275 & & & \\
\hline & $(0.14846)$ & & & \\
\hline \multirow[t]{3}{*}{ GENOTI(-1) } & -0.010897 & & & \\
\hline & $(0.02035)$ & & & \\
\hline & {$[-0.53541]$} & & & \\
\hline \multirow[t]{3}{*}{$\operatorname{EXCH}(-1)$} & 0.509022 & & & \\
\hline & $(0.21532)$ & & & \\
\hline & [2.36405] & & & \\
\hline C & -0.587486 & & & \\
\hline \multirow[t]{3}{*}{ CointEq1 } & -0.113432 & -0.420689 & -0.241059 & -0.067092 \\
\hline & $(0.02500)$ & $(0.44227)$ & $(0.32633)$ & $(0.04003)$ \\
\hline & {$[-4.53812]$} & {$[-0.95120]$} & {$[-0.73871]$} & {$[-1.67621]$} \\
\hline \multirow[t]{3}{*}{$\mathrm{D}(\mathrm{ED}(-1))$} & 0.509464 & 0.814187 & -0.096950 & -0.230819 \\
\hline & $(0.12578)$ & $(2.22554)$ & $(1.64209)$ & $(0.20141)$ \\
\hline & {$[4.05052]$} & [0.36584] & {$[-0.05904]$} & {$[-1.14600]$} \\
\hline \multirow[t]{3}{*}{$D(E D(-2))$} & 0.259991 & -0.170035 & -0.049930 & 0.028214 \\
\hline & $(0.12926)$ & $(2.28723)$ & $(1.68761)$ & $(0.20700)$ \\
\hline & {$[2.01132]$} & {$[-0.07434]$} & {$[-0.02959]$} & [0.13630] \\
\hline \multirow[t]{3}{*}{$D(E D(-3))$} & 0.067026 & 0.363996 & 2.407533 & 0.069143 \\
\hline & $(0.07367)$ & (1.30359) & $(0.96184)$ & (0.11797) \\
\hline & [0.90977] & [0.27923] & {$[2.50306]$} & [0.58608] \\
\hline \multirow[t]{2}{*}{$D(E D(-4))$} & -0.642106 & -0.826820 & -0.995229 & -0.097624 \\
\hline & $(0.07736)$ & $(1.36892)$ & $(1.01004)$ & (0.12389) \\
\hline \multirow{2}{*}{$\mathrm{D}(\mathrm{ED}(-5))$} & $(0.11456)$ & $(2.02711)$ & $(1.49568)$ & $(0.18345)$ \\
\hline & [3.57851] & [0.18986] & {$[-0.55043]$} & {$[-0.04592]$} \\
\hline \multirow[t]{3}{*}{$\mathrm{D}(\mathrm{ED}(-6))$} & 0.213486 & 0.717173 & 0.253322 & 0.081986 \\
\hline & $(0.10968)$ & $(1.94078)$ & $(1.43198)$ & $(0.17564)$ \\
\hline & {$[1.94637]$} & [0.36953] & [0.17690] & [0.46678] \\
\hline \multirow[t]{3}{*}{ D(ROTI(-1)) } & 0.050538 & -0.641271 & 0.055571 & 0.069135 \\
\hline & $(0.01465)$ & $(0.25921)$ & $(0.19126)$ & $(0.02346)$ \\
\hline & [3.44978] & {$[-2.47390]$} & [0.29055] & [2.94708] \\
\hline \multirow[t]{3}{*}{ D(ROTI(-2)) } & 0.040283 & -0.353571 & 0.006260 & 0.074102 \\
\hline & $(0.01491)$ & $(0.26387)$ & (0.19469) & $(0.02388)$ \\
\hline & [2.70130] & {$[-1.33996]$} & [0.03215] & [3.10309] \\
\hline \multirow[t]{3}{*}{ D(ROTI(-3)) } & 0.032206 & -0.317449 & -0.119951 & 0.060916 \\
\hline & $(0.01297)$ & $(0.22943)$ & $(0.16928)$ & $(0.02076)$ \\
\hline & [2.48387] & {$[-1.38366]$} & {$[-0.70860]$} & [2.93384] \\
\hline \multirow[t]{3}{*}{ D(ROTI(-4)) } & 0.008076 & 0.443273 & -0.177103 & 0.049247 \\
\hline & $(0.01142)$ & $(0.20210)$ & $(0.14912)$ & (0.01829) \\
\hline & [0.70703] & [2.19334] & [-1.18768] & [2.69257] \\
\hline \multirow[t]{3}{*}{ D(ROTI(-5)) } & 0.002760 & 0.423052 & -0.232021 & 0.007910 \\
\hline & $(0.01014)$ & (0.17949) & $(0.13243)$ & $(0.01624)$ \\
\hline & [0.27209] & [2.35701] & {$[-1.75200]$} & [0.48699] \\
\hline \multirow[t]{3}{*}{ D(ROTI(-6)) } & 0.002351 & 0.078661 & -0.091316 & -0.002703 \\
\hline & $(0.00764)$ & $(0.13512)$ & (0.09969) & $(0.01223)$ \\
\hline & [0.30791] & [0.58218] & {$[-0.91597]$} & {$[-0.22108]$} \\
\hline \multirow[t]{3}{*}{ D(GENOTI(-1)) } & -0.017080 & 0.140487 & 0.002449 & 0.014481 \\
\hline & $(0.01092)$ & $(0.19324)$ & $(0.14258)$ & (0.01749) \\
\hline & {$[-1.56401]$} & {$[0.72701]$} & [0.01718] & [0.82807] \\
\hline
\end{tabular}


TABLE 1-A1 (Continues...): Vector error correction estimates.

\begin{tabular}{|c|c|c|c|c|}
\hline Error correction: & $D(E D)$ & D(ROTI) & D(GENOTI) & $\mathrm{D}$ (EXCH) \\
\hline \multirow[t]{3}{*}{ D(GENOTI(-2)) } & -0.009873 & -0.084805 & 0.094848 & -0.021071 \\
\hline & $(0.01144)$ & $(0.20246)$ & (0.14938) & $(0.01832)$ \\
\hline & {$[-0.86287]$} & {$[-0.41887]$} & [0.63492] & [-1.14996] \\
\hline \multirow[t]{3}{*}{ D(GENOTI(-3)) } & -0.023824 & -0.273758 & -0.084966 & -0.030515 \\
\hline & $(0.01130)$ & (0.19994) & $(0.14753)$ & (0.01809) \\
\hline & {$[-2.10835]$} & [-1.36918] & {$[-0.57594]$} & {$[-1.68638]$} \\
\hline \multirow[t]{3}{*}{ D(GENOTI(-4)) } & -0.030802 & -0.077042 & 0.288115 & -0.023120 \\
\hline & $(0.01244)$ & $(0.22013)$ & $(0.16242)$ & (0.01992) \\
\hline & [-2.47589] & [-0.34999] & [1.77389] & {$[-1.16052]$} \\
\hline \multirow[t]{3}{*}{ D(GENOTI(-5)) } & -0.001345 & -0.219362 & 0.066641 & -0.021640 \\
\hline & $(0.01274)$ & $(0.22547)$ & $(0.16636)$ & $(0.02040)$ \\
\hline & {$[-0.10558]$} & [-0.97293] & [0.40059] & {$[-1.06055]$} \\
\hline \multirow[t]{3}{*}{ D(GENOTI(-6)) } & 0.008745 & 0.105475 & -0.113405 & 0.015815 \\
\hline & $(0.01263)$ & $(0.22350)$ & (0.16491) & $(0.02023)$ \\
\hline & [0.69236] & [0.47193] & {$[-0.68769]$} & [0.78187] \\
\hline \multirow[t]{3}{*}{$\mathrm{D}(\mathrm{EXCH}(-1))$} & 0.024127 & 1.585671 & 0.477535 & 0.552556 \\
\hline & $(0.08685)$ & $(1.53677)$ & (1.13389) & (0.13908) \\
\hline & [0.27780] & [1.03182] & [0.42115] & [3.97299] \\
\hline \multirow[t]{3}{*}{$\mathrm{D}(\mathrm{EXCH}(-2))$} & 0.144663 & -0.172261 & -0.719269 & 0.166915 \\
\hline & $(0.09881)$ & $(1.74837)$ & (1.29001) & $(0.15823)$ \\
\hline & [1.46406] & {$[-0.09853]$} & {$[-0.55757]$} & [1.05491] \\
\hline \multirow[t]{3}{*}{$\mathrm{D}(\mathrm{EXCH}(-3))$} & 0.069737 & 0.421250 & -0.476492 & 0.105299 \\
\hline & $(0.08573)$ & $(1.51695)$ & (1.11926) & $(0.13728)$ \\
\hline & [0.81344] & {$[0.27770]$} & {$[-0.42572]$} & [0.76702] \\
\hline \multirow[t]{3}{*}{$\mathrm{D}(\mathrm{EXCH}(-4))$} & 0.461503 & 0.014257 & -0.512343 & -0.478010 \\
\hline & $(0.08251)$ & (1.45999) & (1.07724) & $(0.13213)$ \\
\hline & [5.59317] & {$[0.00976]$} & {$[-0.47561]$} & {$[-3.61774]$} \\
\hline \multirow[t]{3}{*}{$\mathrm{D}(\mathrm{EXCH}(-5))$} & -0.132806 & -2.577539 & 0.548396 & 0.366085 \\
\hline & $(0.11334)$ & $(2.00548)$ & $(1.47972)$ & $(0.18150)$ \\
\hline & {$[-1.17174]$} & {$[-1.28525]$} & {$[0.37061]$} & [2.01704] \\
\hline \multirow[t]{3}{*}{$\mathrm{D}(\mathrm{EXCH}(-6))$} & 0.033446 & -1.067723 & 0.848060 & 0.149730 \\
\hline & (0.10812) & $(1.91313)$ & (1.41158) & $(0.17314)$ \\
\hline & [0.30934] & {$[-0.55810]$} & {$[0.60079]$} & [0.86480] \\
\hline \multirow[t]{3}{*}{ C } & 0.010782 & -0.046330 & -0.041878 & -0.012128 \\
\hline & $(0.01210)$ & $(0.21402)$ & (0.15791) & (0.01937) \\
\hline & {$[0.89145]$} & {$[-0.21648]$} & {$[-0.26520]$} & {$[-0.62618]$} \\
\hline R-squared & 0.866813 & 0.862843 & 0.521001 & 0.639135 \\
\hline Adj. R-squared & 0.801525 & 0.795609 & 0.286197 & 0.462240 \\
\hline Sum sq. resids & 0.474880 & 148.6791 & 80.94164 & 1.217725 \\
\hline S.E. equation & 0.096495 & 1.707418 & 1.259798 & 0.154522 \\
\hline F-statistic & 13.27676 & 12.83342 & 2.218881 & 3.613084 \\
\hline Log likelihood & 86.64889 & -134.5907 & -111.1803 & 50.39434 \\
\hline Akaike AIC & -1.575296 & 4.171186 & 3.563125 & -0.633619 \\
\hline Schwarz SC & -0.783881 & 4.962601 & 4.354540 & 0.157796 \\
\hline Mean dependent & -0.009274 & -0.061039 & -0.037662 & -0.039247 \\
\hline S.D. dependent & 0.216598 & 3.776665 & 1.491117 & 0.210715 \\
\hline Determinant resid covariance (dof adj.) & & 0.000940 & & \\
\hline Determinant resid covariance & & 0.000181 & & \\
\hline Log likelihood & & -105.2408 & & \\
\hline Akaike information criterion & & 5.538721 & & \\
\hline Schwarz criterion & & 8.826137 & & \\
\hline
\end{tabular}

